\title{
PENGGUNAAN KOLOM KROMATOGRAFI INTERAKSI HIDROFOBIK UNTUK PEMURNIAN KITOSANASE
}

\author{
Ekowati Chasanah"), Maggy T. Suhartono"), dan Sumpeno Putro")
}

\begin{abstract}
ABSTRAK
Penelitian ini bertujuan untuk melihat performansi metode purifikasi dengan kromatografi kolom interaksi hidrofobik untuk memurnikan enzim kitosanase yang diisolasi dari Bacillus licheniformis MB-2. Matriks Butyl Sepharose 4FF telah digunakan untuk memisahkan enzim kitosanase dari campuran enzim yang ada pada ekstrak kasar. Konsentrasi amonium sulfat optimal yang diperlukan untuk memaksimalkan interaksi tersebut adalah $30 \%$ tingkat kejenuhan (TK). Profil elusi menggunakan gradien amonium sulfat $30 \%-0 \%$ TK menghasikan 2 fraksi aktif kitosanase, yaitu $F 1$ dan F2, dan ketika elusi dilakukan dengan larutan amonium sulfat $10 \%-0 \%$ TK, didapatkan 2 fraksi aktif tambahan yaitu F3 dan F4. Pengecekan kemurnian dengan elektroforesis terdenaturasi (SDS-PAGE) yang diwarnai dengan larutan perak nitrat memperlihatkan bahwa fraksi F2 telah murni, yang ditunjukkan oleh adanya 1 pita pada gel SDSPAGE tersebut, sedangkan fraksi F1, F3 dan F4 belum murni. Penggunaan kolom kromatografi dengan matriks interaksi hidrofobik berhasil memisahkan satu fraksi murni (F2) dengan perolehan $29 \%$.
\end{abstract}

\section{ABSTRACT : Application of hydrophobic interaction chromatography for chitosanase pu- rification. By: Ekowati Chasanah, Maggy T. Suhartono, and Sumpeno Putro}

The objective of the study was to obtain hydrophobic interaction chromatography performance for purification of Bacillus licheniformis MB-2 chitosanase. Butyl Sepharose 4FF matrix was used to fractionate the enzyme from crude extract. The optimum concentration of ammonium sulphate used to maximize hydrophobic interaction was $30 \%$ saturation. The fractionation resulted 2 active peaks, i.e $F 1$ and $F 2$, when elution was done using gradient ammonium sulphate of 30\%-0\% saturation, while 2 more active peaks, F3 and F4, were obtained when lower amonium sulphate gradient was used, i.e 10\%-0\% saturation. SDS-PAGE analysis showed that F2 was relatively pure indicated by 1 band of protein in the gel, while F1, F3 and F4 were not. It can be concluded that pure fraction of $F 2(29 \%)$ can be obtained by single step purification by hydrophobic interaction of coloumn chromatography

KEYWORDS: hydrophobic interaction chromatography, purification, chitosanase

\section{PENDAHULuAN}

Enzim kitosanase merupakan enzim yang penting untuk menghasilkan kitosan oligomer yang bermutu tinggi dan bersifat ramah lingkungan. Produk kitosan oligomer hasil hidrolisis enzim tersebut akhir-akhir ini sangat populer karena mempunyai sifat fungsional yang bermanfaat untuk kesehatan manusia, misalnya mampu menghambat pertumbuhan sel kanker, mengikat kolesterol dan lemak dalam saluran pencernaan,dll. (Tsigos et al., 2000; Anon., 2001). Karena itu, kitosan oligomer telah digunakan sebagai komponen utama berbagai produk suplemen kesehatan ataupun produk medis yang memiliki pasar sangat baik. Untuk aplikasi medis, diperlukan beberapa syarat antara lain ukuran oligomer yang lebih seragam dengan kemurnian tinggi.
Apabila diinginkan produk oligomer dengan ukuran yang seragam maka diperlukan enzim yang relatif murni sehingga dihasilkan produk turunan yang bersifat sangat spesifik, sesuai dengan target dan tidak tercampur dengan produk enzim lain. Enzim murni juga diperlukan apabila ingin mempelajari lebih lanjut karakter enzim tersebut, termasuk di dalamnya kinetika, struktur enzim dan urutan protein penyusunnya. Dengan mengetahui struktur dan urutan asam amino terutama pada dan di sekitar sisi aktifnya, maka rekayasa protein dan rekayasa genetika dapat dilakukan, sehingga enzim yang lebih stabil dan ekonomis dapat diproduksi secara masal.

Dari penelitian terdahulu diketahui bahwa enzim kasar kitosanase Bacillus licheniformis MB-2 memiliki karakteristik unik yaitu bersifat tahan panas. Enzim

- Peneliti pada Balai Besar Pengolahan Produk dan Bioteknologi Kelautan dan Perikanan

*) Peneliti pada Pusat Riset Bioteknologi Institut Pertanian Bogor 
ini bekerja optimal pada suhu $80^{\circ} \mathrm{C}$ dan $\mathrm{pH} 6$ (Chasanah et al., 2002). Upaya untuk mendapatkan enzim murni sangat diperlukan untuk mengetahui karakteristik lebih lanjut enzim tersebut dan aplikasi komersial ke depannya.

Dalam menentukan metode pemurnian yang akan digunakan, maka informasi tentang protein, di antaranya titik isoelektris dan komposisi asam amino penyusun protein enzim sangat diperlukan. Karena minimnya informasi tersebut pada enzim kasar, maka pendekatan dari beberapa pustaka telah dilakukan. Kitosanase yang dihasilkan oleh bakteri memiliki kisaran titik isoelektris pada $\mathrm{pH} 7,5-10,1$ dan berat molekul 27-85,62 kD (Somashekar \& Joseph, 1996; Kimoto et al., 2002). Beberapa matriks yang telah digunakan untuk memurnikan kitosanase di antaranya adalah kombinasi antara penukar anion/kation dan gel filtrasi (Seino et al., 1991; Yoshihara et al., 1992; Shimosaka et al., 1995; Kurakake et al., 2000; Kimoto et al., 2002; Choi et al., 2004), sedangkan Park et al. (1999) melaporkan penggunaan isoelectric focusing (IF) setelah pemakaian gel filtrasi. Upaya penggunaan kolom kromatografi menggunakan matriks penukar kation (CM-Sepharose) maupun anion (DEAE Sepharose) untuk memurnikan enzim kitosanase $B$. licheniformis MB-2 ternyata tidak berhasil, dan yield atau perolehannya sangat kecil (Chasanah, 2002). Karena itu, alternatif penggunaan matriks selain penukar kation dan anion perlu dicoba.

Dalam penelitian ini dicoba penggunaan kromatografi kolom menggunakan matriks interaksi hidrofobik untuk memurnikan kitosanase $B$. licheniformis MB-2. Metode ini merupakan metode yang mild dan dilaporkan memiliki perolehan dan kapasitas tinggi (Roe, 1989; Eriksson, 1998). Dalam kromatografi ini, campuran protein yang akan dipisahkan berfungsi sebagai fase bergerak, sedangkan matriks yang memiliki ligan hidrofobik berfungsi sebagai fase diam. Tujuan dari penelitian ini adalah untuk mendapatkan performansi metode pemurnian berdasar pada interaksi hidrofobik untuk kitosanase $B$. licheniformis MB-2.

\section{BAHAN DAN METODE}

\section{Bahan Kimia}

Butyl Sepharose 4FF, Sephadex G-75, kitin dan kitosan ( $85 \%$ deasetilasi) serta bahan-bahan untuk pembuatan larutan penyangga diperoleh dari Sigma. Kitosan koloidal (sekitar $76 \%$ deasetilasi) dibuat secara kimia sesuai metode Trudel \& Asselin (1989). Semua reagen dan bahan mikrobiologi yang digunakan adalah grade analitik.

\section{Produksi Enzim}

Enzim diproduksi menggunakan media yang telah dioptimasi, berisi $0,24 \%$ kitosan, $0,25 \%$ casiton, $1 \%$ $\mathrm{MgSO}_{4}, 1,4 \% \mathrm{~K}_{2} \mathrm{HPO}_{4}, 0,02 \% \mathrm{CaCl}_{2} .2 \mathrm{H}_{2} \mathrm{O}, 0,002 \%$ $\mathrm{FeSO}_{4} \cdot 7 \mathrm{H}_{2} \mathrm{O}$. Sebanyak $15 \%$ starter (dari 1 loop bakteri, umur starter 20 jam) digunakan untuk menginokulasi medium cair, dan diinkubasi 7 hari dalam penangas air pada suhu $55^{\circ} \mathrm{C}$ dan diaduk pada $120 \mathrm{rpm}$. Ekstrak kasar enzim diperoleh dengan melakukan sentrifugasi pada $4000 \mathrm{~g}$ selama 30 menit pada $4^{\circ} \mathrm{C}$, dan selanjutnya, supernatan (ekstrak enzim kasar) disimpan dalam refrigerator bersuhu $4^{\circ} \mathrm{C}$. Sodium azide sebanyak $0,02 \%(\mathrm{~b} / \mathrm{v})$ ditambahkan ke dalam ekstrak tersebut untuk mengawetkan

\section{Penelitian Pendahuluan}

Penelitian pendahuluan ditujukan untuk mendapatkan penyerapan tertinggi atau protein target terbuang yang paling rendah pada matriks berligan hidrofobik. Konsentrasi amonium sulfat yang dicobakan adalah 10\%, 20\% dan 30\% tingkat kejenuhan (TK) yang dihitung berdasarkan Tabel Presipitasi Ammonium Sulfat (Bollag \& Edelstein, 1991). Disiapkan 3 kolom mini (tip berukuran $10 \mathrm{~mL}$ dengan ujung tip diberi kapas), dan diisi masing-masing dengan $2 \mathrm{~mL}$ matriks Butyl Sepharose 4FF. Ke dalam kolom tersebut dimasukkan $15 \mathrm{~mL}$ air bebas ion, diikuti dengan larutan amonium sulfat $10 \%, 20 \%$ dan $30 \%$ TK, masing-masing untuk kolom 1, 2 dan 3 . Sebanyak $5 \mathrm{~mL}$ enzim kasar ( 3 set) masing-masing ditambahkan amonium sulfat $(10 \%, 20 \%$ dan $30 \%$ TK), dan dilarutkan perlahan-lahan pada kondisi dingin $\left(4^{\circ} \mathrm{C}\right)$. Masing-masing enzim kasar yang telah ditambah dengan amonium sulfat tersebut dialirkan ke dalam kolom yang telah diekuilibrasi disesuaikan dengan perlakuan. Tetesan buangan ditampung, dianalisis, dan dihitung sebagai protein target terbuang (TO) Elusi protein yang terikat dilakukan dengan mengalirkan $8 \mathrm{~mL}$ larutan amonium sulfat $(10 \%, 20 \%$, $30 \%$ TK) pada kolom 1,2 dan 3 yang dilanjutkan dengan mengalirkan larutan penyangga fosfat $20 \mathrm{mM}$, $\mathrm{pH} 6$ (konsentrasi amonium sulfat $0 \%$ ). Tetesan eluen ditampung dan dianalisis.

\section{Pemurnian Berdasar Interaksi Hidrofobik}

Pemurnian dilakukan pada suhu ruangan berpendingin $\left(20^{\circ} \mathrm{C}\right)$. Kolom $(0,5 \times 15,5 \mathrm{~cm})$ dipak dengan matriks Butyl Sepharose 4 FF dan diekuilibrasi dengan larutan penyangga fosfat $0,05 \mathrm{M}(\mathrm{pH} 6)$ yang berisi amonium sulfat ( $30 \%$ TK). Enzim kasar $(75 \mathrm{~mL})$ yang telah ditambah amonium sulfat (30\% TK) dialirkan ke dalam kolom dengan kecepatan $14 \mathrm{~mL}$ / jam. Kolom selanjutnya dicuci dengan larutan 
penyangga fosfat $0,02 \mathrm{M}(\mathrm{pH} 6)$ yang telah ditambah amonium sulfat ( $30 \% \mathrm{TK})$. Elusi dilakukan dengan menggunakan larutan penyangga fosfat $0,02 \mathrm{M} \mathrm{pH} 6$ yang mempunyai gradien amonium sulfat $(30 \%-0 \%$ TK), dengan kecepatan alir 2-4 mLjam. Setiap fraksi ( 3 dan $5 \mathrm{~mL}$ ) dianalisis enzim kitosanase dan kadar proteinnya dengan mengukur absorbansi pada 280 $\mathrm{nm}$. Fraksi positif dikumpulkan (F1) dan dikonsentrasikan dengan ultrafiltrasi yang memiliki ukuran pemisahan $10 \mathrm{kD}$ menggunakan Vivaspin (1000-3000 $\mathrm{rpm}, 4^{\circ} \mathrm{C}, 3$ menit). Protein enzim yang berukuran $>$ $10 \mathrm{kD}$ tetap berada di atas membran, sehingga dapat dipisahkan dari materi yang berukuran $<10 \mathrm{kD}$ yang akan lolos ke bawah melalui membran tersebut.

\section{Pemurnian Berdasarkan Ukuran Molekul (Filtrasi Gel)}

Tahap ini merupakan lanjutan dari tahap pemurnian di atas, yaitu untuk F1. Matriks yang digunakan adalah Sephadex G-75. Sebanyak 1,5 gram Sephadex G-75 direndam dalam larutan penyangga fosfat 0,05 $\mathrm{M} \mathrm{pH} 6$ selama 12 jam di penangas air bersuhu $80^{\circ} \mathrm{C}$. Setelah tahapan penghilangan gas, matriks dipak ke dalam kolom berukuran $40 \times 1 \mathrm{~cm}$, dan ekuilibrasi dilakukan dengan mengalirkan $50 \mathrm{~mL}$ larutan penyangga fosfat $0,05 \mathrm{M} \mathrm{pH} 6$. Sampel fraksi F1 sebanyak $2 \mathrm{~mL}$, setelah dikonsentrasikan, dialirkan ke dalam kolom. Elusi dilakukan dengan larutan penyangga yang sama dengan mengatur kecepatan tetesan $4 \mathrm{~mL} / \mathrm{jam}$. Fraksi $(1,5 \mathrm{~mL})$ ditampung dan dianalisis kadar protein (absorbansi pada $280 \mathrm{~nm}$ ) dan kitosanasenya.

\section{Esai Enzim Kitosanase}

Esai enzim kitosanase dilakukan menurut Yoon et al. (2001) dengan modifikasi. Campuran reaksi (100 $\mu \mathrm{L}$ kitosan larut air $1 \%, 100 \mu \mathrm{L} 0,05 \mathrm{M}$ penyangga fosfat $\mathrm{pH} 6$ dan $100 \mu \mathrm{L}$ enzim) diinkubasikan pada suhu optimum enzim murni $\left(70^{\circ} \mathrm{C}\right)$ selama 30 menit.
Reaksi dihentikan dengan membekukan campuran reaksi selama 15 menit di dalam freezer. Jumlah produk yang terbentuk dideteksi dengan reaksi pewarnaan Schales (Uchida \& Ohtakara, 1998) sebagai berikut : $200 \mu \mathrm{L}$ campuran reaksi ditambah dengan $800 \mu \mathrm{L}$ akuades dan $1 \mathrm{~mL}$ reagen Schales. Selanjutnya tabung reaksi yang berisi campuran tersebut dididihkan selama 15 menit, disentrifugasi pada $300 \mathrm{~g}$ selama 10 menit. Absorbansi dibaça pada $\lambda=420 \mathrm{~nm}$. Blanko disiapkan dengan mengganti sampel dengan akuades. Satu unit aktivitas kitosanase didefinisikan sebagai jumlah enzim yang mampu menghasilkan $1 \mu \mathrm{mol}$ gula reduksi (glukosamin) per menit.

\section{Elektroforesis}

Elektroforesis dilakukan secara terdenaturasi (SDS-PAGE) untuk mengecek kemurnian enzim. SDS-PAGE dilakukan pada gel akrilamid $10 \%$, pada 50 volt dan $25 \mathrm{~mA}$. Fraksi aktif hasil pemurnian (100 $\mu \mathrm{L}$ ) dikonsentrasikan dengan TCA $10 \%$, dan endapan yang diperoleh diberi $15 \mu \mathrm{L}$ larutan penyangga sampel ( $15 \%$ sukrosa, $2,5 \%$ sodium dodesil sulfat dalam 125 $\mathrm{mM}$ Tris-Cl pH 6,7). Setelah diresuspensikan dengan larutan penyangga tersebut, sampel diinkubasikan dalam penangas air yang mendidih selama 5 menit, dan dimasukkan ke dalam sumur gel. Setelah proses pemisahan berakhir, gel diwarnai dengan larutan perak nitrat (Bollag \& Edelstein, 1991).

\section{HASIL DAN BAHASAN}

Hasil penelitian pendahuluan (Tabel 1) menunjukkan bahwa protein target dapat diikat secara maksimal atau terbuang/lolos secara minimal ketika digunakan larutan amonium sulfat (30\% TK). Pada penggunaan amonium sulfat dengan konsentrasi $30 \%$ TK tersebut, protein target yang lolos atau tidak menempel pada matriks adalah paling rendah yaitu $15 \%$. Garam, dalam penelitian ini digunakan amonium

Tabel 1. Aktivitas kitosanase pada ekstrak kasar (K), yang terikat pada matriks (B) dan terbuang (TO)

Table 1. Chitosanase activity of crude extract (K), bound at matrix (B) and through out (TO) sample

\begin{tabular}{cccc}
\hline $\begin{array}{c}\text { TK amm sulfat/ } \\
\text { Saturation degree of } \\
\text { ammonium sulphate }\end{array}$ & \multicolumn{2}{c}{ Aktivitas kitosanase (U/mL)*/Chitosanase activity (U/mL) } \\
\cline { 2 - 4 } & $\mathrm{K}$ & $\mathrm{B}(\mathrm{yield})$ & TO (yield) \\
\hline $10 \%$ & $1.143 \pm 0.001$ & $0.699 \pm 0.002(51.9 \%)$ & $0.482 \pm 0.002(42.2 \%)$ \\
$20 \%$ & $1.559 \pm 0.002$ & $0.623 \pm 0.001(40 \%)$ & $0.456 \pm 0.002(29.2 \%)$ \\
$30 \%$ & $1.428 \pm 0.002$ & $0.968 \pm 0.001(68 \%)$ & $0.219 \pm 0.001(15.3 \%)$ \\
\hline Catatan/Note: * merupakan nilai rata-rata dari 2 ulangan/Average value of 2 replications
\end{tabular}


sulfat, diperlukan untuk mendukung terjadinya interaksi hidrofobik antara protein target dengan matriks yang memiliki ligan gugus hidrofobik. Dalam suasana pelarut yang mengandung amonium sulfat (30\% TK), interaksi hidrofobik antara protein target dengan matriks menjadi maksimal sehingga protein yang lolos minimal. Untuk selanjutnya maka amonium sulfat $30 \%$ TK digunakan pada kolom interaksi hidrofobik untuk memisahkan kitosanase dari Bacillus licheniformis MB-2.

Kemampuan protein untuk menempel/berinteraksi dengan matriks ditentukan oleh jumlah asam amino hidrofobik pada protein target. Meskipun secara umum asam amino hidrofilik lebih mendominasi permukaan protein pada struktur tiga dimensinya, beberapa asam amino hidrofobik diketahui pula berada di permukaan protein. Jumlah dan komposisi asam amino hidrofobik pada setiap protein ini nantinya yang menentukan seberapa kuat interaksi tersebut, yang membedakan antara satu protein dengan protein lain dan mendasari pemisahan pada teknik ini (Roe, 1989; Eriksson, 1998). Pemisahan dilakukan dengan mengelusi protein menggunakan gradien negatif larutan garam, dan protein yang bersifat kurang hidrofobik akan terelusi lebih dulu atau terlepas pada konsentrasi garam yang lebih tinggi dibanding protein yang bersifat lebih hidrofobik

Hasil pemisahan kitosanase dapat dilihat pada Gambar 1 ketika elusi dilakukan dengan menggunakan gradien amonium sulfat $30 \%-0 \%$ TK. Dari profil tersebut, didapat 2 fraksi positif yaitu F1 dan F2. Dari hasil tersebut dapat disimpulkan bahwa kitosanase yang ada pada $\mathrm{F} 1$ bersifat lebih tidak hidrofobik dibanding kitosanase $\mathrm{F} 2$.

Ketika gradien garam yang digunakan untuk elusi diperkecil, yaitu $15 \%-0 \%$ TK, dengan kecepatan elusi yang lebih rendah, maka terlihat 2 puncak kecil fraksi di antara F1 dan F2, dan menjadi lebih jelas ketika digunakan gradien garam yang lebih rendah yaitu $10 \%$ 0\% TK (Gambar 2 dan 3). Mempersempit kisaran gradien garam merupakan salah satu teknik yang biasa digunakan untuk memperoleh pemisahan yang maksimal ketika telah diketahui kisaran konsentrasi untuk pemisahan (Roe, 1989; Eriksson, 1998). Selain amonium sulfat, gradien garam $\mathrm{NaCl}$ juga biasa dipergunakan untuk melepaskan protein pada teknik

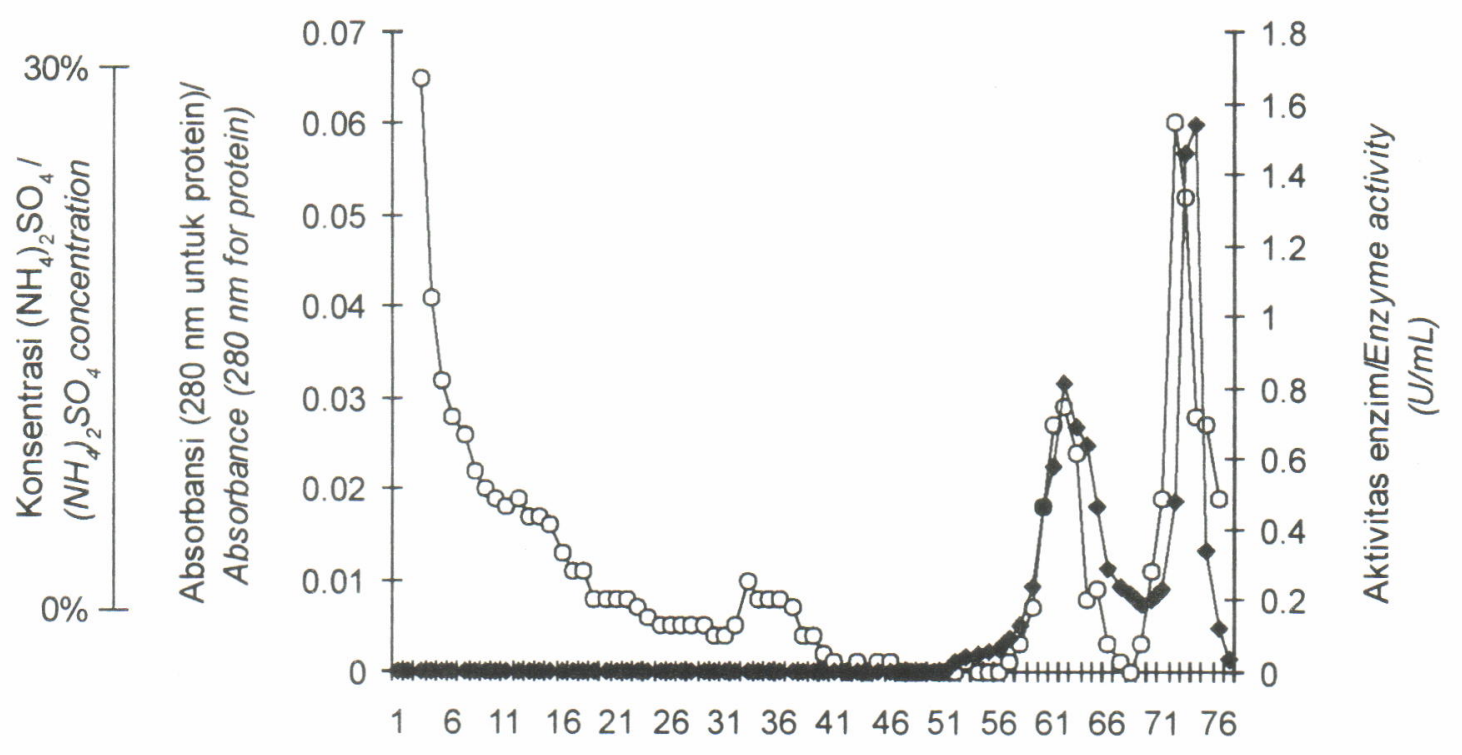

Nomor fraksi/Fraction number

$\rightarrow$ Absorbance $\rightarrow(\mathrm{U} / \mathrm{mL})-\left(\mathrm{NH}_{4}\right)_{2} \mathrm{SO}_{4}(30 \%-0 \%)$

Gambar 1. Profil elusi enzim kasar kitosanase B. licheniformis MB-2 dengan gradient amonium sulfat $30 \%-$ $0 \%$ TK. (Keterangan: volume enzim kasar $75 \mathrm{~mL}$, dengan kadar protein $0,277 \mathrm{mg} / \mathrm{mL}$, dan kecepatan elusi $4 \mathrm{~mL} / \mathrm{jam}$ ).

Figure 1. Elution profile of $\boldsymbol{B}$. licheniformis MB-2 crude chitosanase using gradient ammonium sulphate of $30 \%-0 \%$ saturation (Note: volume of enzyme applied was $75 \mathrm{~mL}$, protein content $0.277 \mathrm{mg} / \mathrm{mL}$, elution speed of $4 \mathrm{~mL} / \mathrm{h}$ ). 

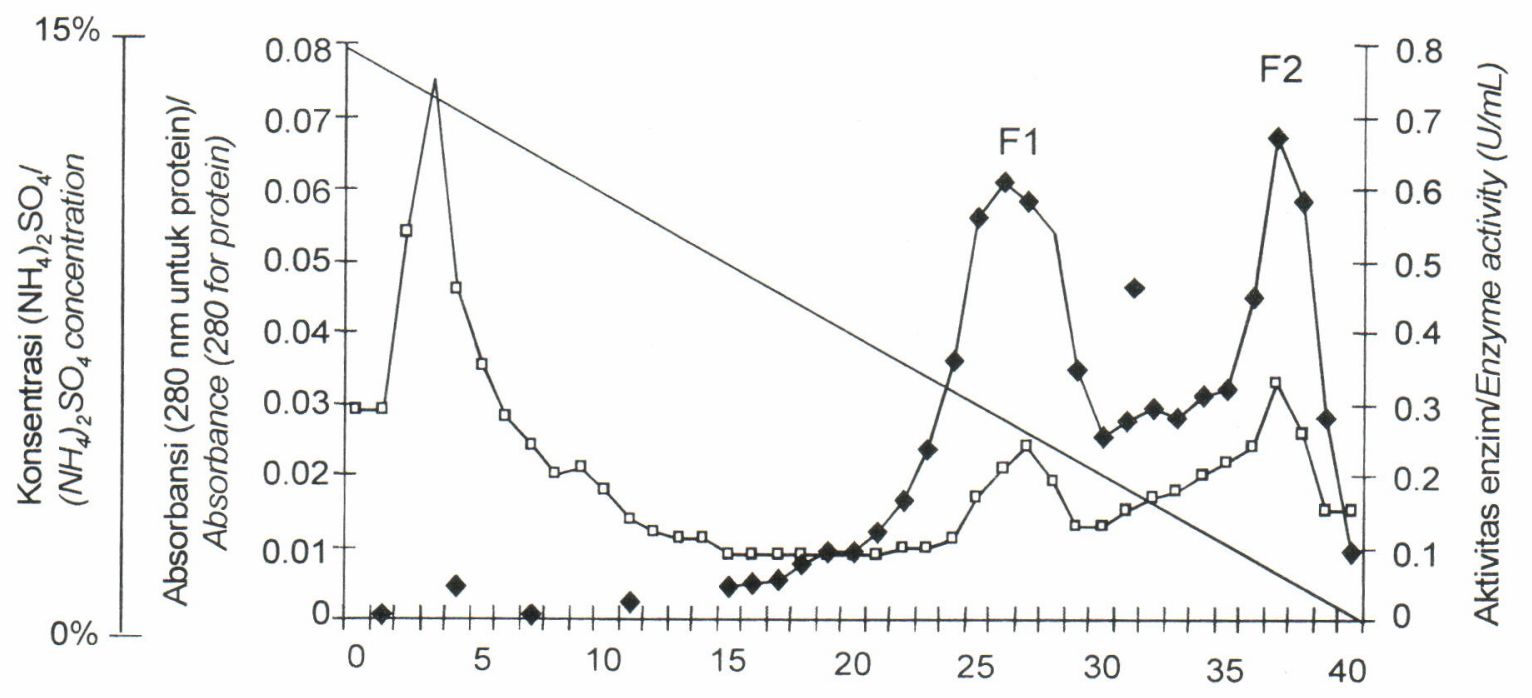

Nomor fraksi/Fraction number

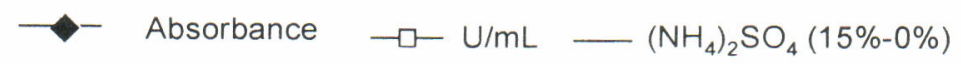

Gambar 2. Profil elusi enzim kasar kitosanase B. licheniformis MB-2 dengan gradien amonium sulfat $15 \%$ $0 \%$ TK. (Keterangan : volume enzim kasar $75 \mathrm{~mL}$, dengan kadar protein 0,277 mg/mL. Kecepatan elusi $4 \mathrm{~mL} / \mathrm{jam}$ )

Figure 2. Elution profile of $B$. licheniformis MB-2 crude chitosanase using gradient ammonium sulphate of $15 \%-0 \%$ (Note : volume of enzyme applied was $75 \mathrm{~mL}$, protein content $0.277 \mathrm{mg} / \mathrm{mL}$, elution speed of $4 \mathrm{~mL} / \mathrm{h})$.

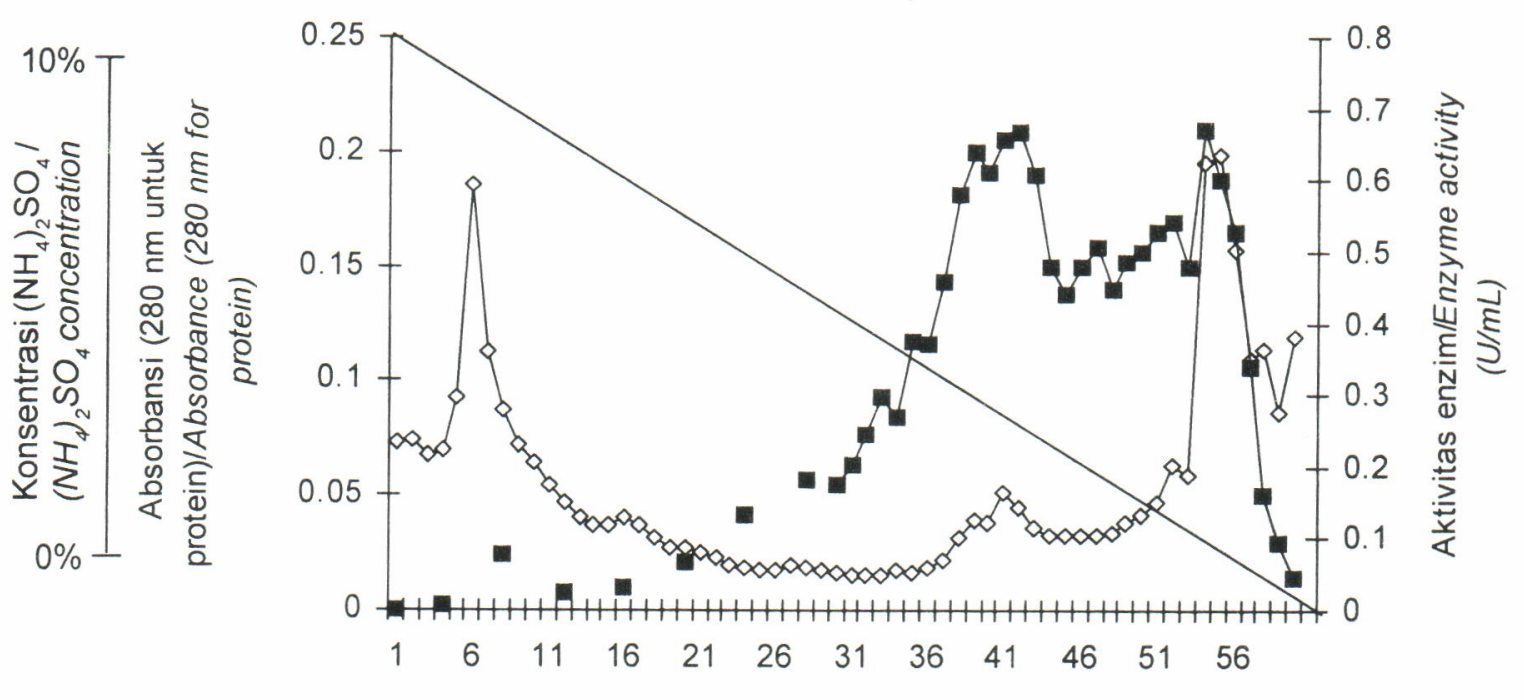

No fraksi/Fraction number

$\multimap$ Absorbance $\rightarrow \mathrm{U} / \mathrm{mL}-\left(\mathrm{NH}_{4}\right)_{2} \mathrm{SO}_{4}(10 \%-0 \%)$

Gambar 3. Profil elusi enzim kasar kitosanase B. licheniformis MB-2 dengan gradien amonium sulfat $10 \%-$ $0 \%$ TK. (Keterangan : volume enzim kasar $75 \mathrm{~mL}$, dengan kadar protein 0,277 mg/mL, dan kecepatan elusi $2 \mathrm{~mL} / \mathrm{jam}$ ).

Figure 3. Elution profile of $\boldsymbol{B}$. licheniformis MB-2 crude chitosanase using gradient ammonium sulphate of $10 \%-0 \%$ (Note : volume of enzyme applied was $75 \mathrm{~mL}$, protein content $0.277 \mathrm{mg} / \mathrm{mL}$, elution speed of $2 \mathrm{~mL} / \mathrm{h})$. 
kromatografi jenis ini. Deterjen juga sering ditambahkan pada larutan pengelusi apabila yang dimurnikan adalah protein membran.

Gambar 4 adalah pita-pita protein pada SDS-PAGE yang memperlihatkan tingkat kemurnian fraksi-fraksi hasil pemisahan. Fraksi F1, F3 dan F4 masih belum murni yang ditunjukkan oleh adanya lebih dari satu pita protein pada gel, sedangkan $\mathrm{F} 2$ terlihat sebagai pita tunggal, yang berarti F2 sudah murni. Kemampuan memurnikan kitosanase melalui satu kali tahap pemurnian seperti F2 merupakan keberhasilan yang jarang dilaporkan (Seino et al., 1991; Yoshihara et al., 1992; Shimosaka et al., 1995; Park et al.,1999; Kurakake et al., 2000; Kimoto et al., 2002; Choi et al., 2004). Kitosanase yang diisolasi dari Aspergillus adanya perbedaan struktur kitosanase $B$. licheniformis MB-2 dengan kitosanase dari mikroba lain. Asam amino non polar diduga berjumlah lebih banyak pada struktur luar kitosanase $B$. licheniformis MB-2 dibanding kitosanase yang selama ini dilaporkan.

Pemurnian lanjutan dilakukan terhadap fraksi F1 dengan filtrasi gel menggunakan matriks Sephadex G-75yang memiliki kemampuan memisahkan molekul dengan ukuran 18-75 kD. Sebelum dimasukkan ke dalam kolom gel filtrasi, fraksi F1 dikonsentrasikan ke dalam tabung ultrafiltrasi yang memiliki ukuran saringan $10 \mathrm{kD}$. Molekul dengan ukuran $\geq 10 \mathrm{kD}$, termasuk protein enzim, akan tertahan, sedangkan yang di bawah $10 \mathrm{kD}$ seperti garam akan terbuang.

$\begin{array}{lllll}\text { F2 } & \text { F3 } & \text { F4 } & \text { F1 } & \text { LMW }\end{array}$

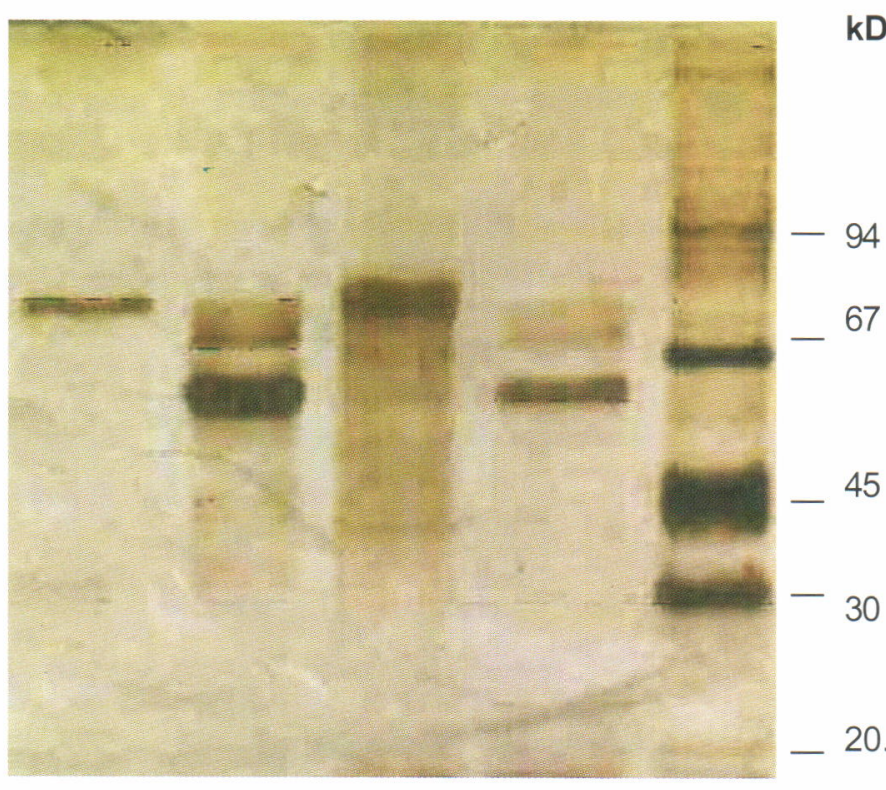

\section{kDalton}

4 67 5

Gambar 4. Hasil SDS-PAGE fraksi-fraksi aktif pada kolom kromatografi dengan elusi gradien amonium sulfat $10 \%-0 \%$ TK.

Figure 4. SDS-PAGE of active fractions eluted by gradient of $10 \%-0 \%$ ammonium sulphate.

dilaporkan dapat dimurnikan dengan satu tahap pemurnian dengan kromatografi penukar kation (Cheng \& Li, 2000). Karena itu, laporan ini diduga merupakan laporan pertama pemurnian enzim kitosanase dari bakteri melalui satu tahap pemurnian menggunakan kromatografi interaksi hidrofobik (Seino et al., 1991; Yoshihara et al., 1992; Shimosaka et al., 1995; Park et al., 1999; Kurakake et al., 2000; Kimoto et al., 2002; Choi et al., 2004). Keberhasilan pemurnian kitosanase ini dengan kolom kromatografi interaksi hidrofobik menunjukkan kemungkinan
Dari profil elusi fraksi F1 yang dipisahkan dengan Sephadex G-75 (Gambar 5), ternyata F1 terpisah menjadi 2 fraksi, yaitu fraksi mayor (F1a) dan minor (F1b). Namun demikian, pada pengecekan dengan SDS-PAGE yang diberi substrat kitosan, ternyata masih terdapat 2 pita kitosanase (Gambar 6). Hal ini dapat diartikan bahwa kemungkinan pertama pemisahan dengan Sephadex G-75 belum mampu memisahkan campuran enzim kitosanase yang ada pada fraksi tersebut, atau enzim kitosanase yang terdapat pada fraksi F1a tersebut memang terdiri dari 


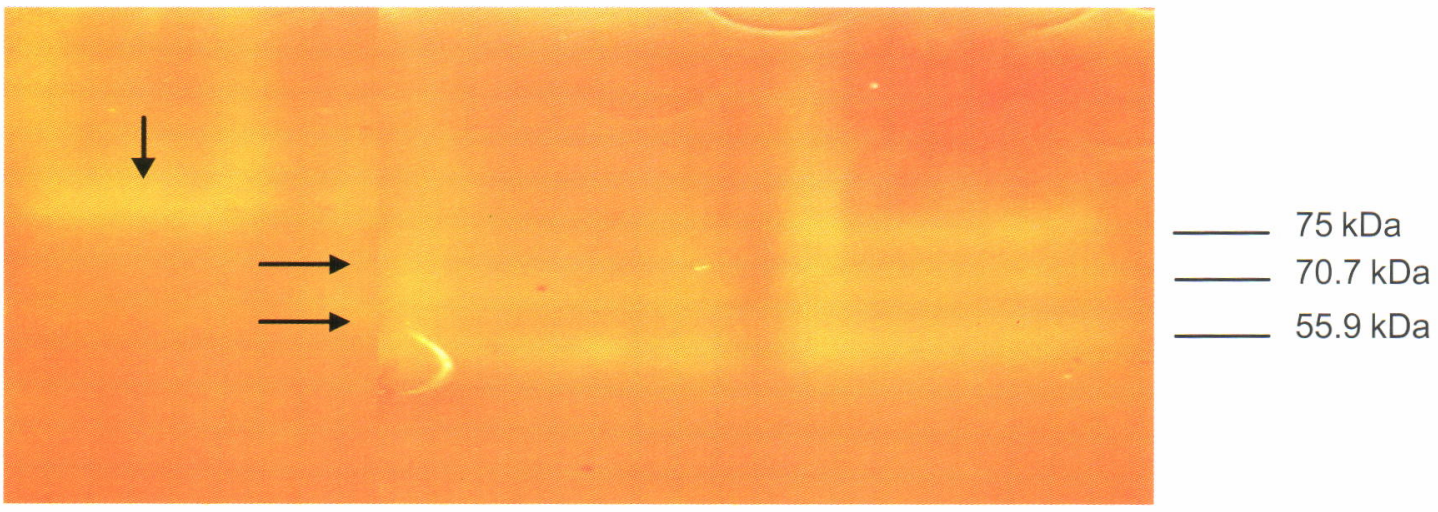

Gambar 5. Hasil zymogram (gel SDS-PAGE yang di letakkan di atas gel substrat) enzim kasar (broth), F1a dan F2.

Figure 5. Zymogram analysis (SDS-PAGE gel overlaid with substrate gel) of crude broth, F1a and F2 chitosanase enzyme.

2 unit protein yang tidak dapat dipisahkan. Pengecekan ulang ke elektroforesis non denaturan (PAGE native) harus dilakukan untuk membuktikan apakah enzim kitosanase yang ada pada F1a berupa protein yang memiliki 2 unit (enzim dimer) atau memang terdiri dari 2 protein enzim ( 2 enzim monomer).
Kedua tahap pemurnian, baik dengan kolom interaksi hidrofobik maupun dengan kolom gel filtrasi dilakukan pada ruang bersuhu $20^{\circ} \mathrm{C}$, karena protein yang dimurnikan bersifat stabil terhadap panas. Meskipun tidak ada pengaturan dalam mengatur kecepatan elusi, namun beberapa pengalaman memperlihatkan bahwa mengatur kecepatan elusi

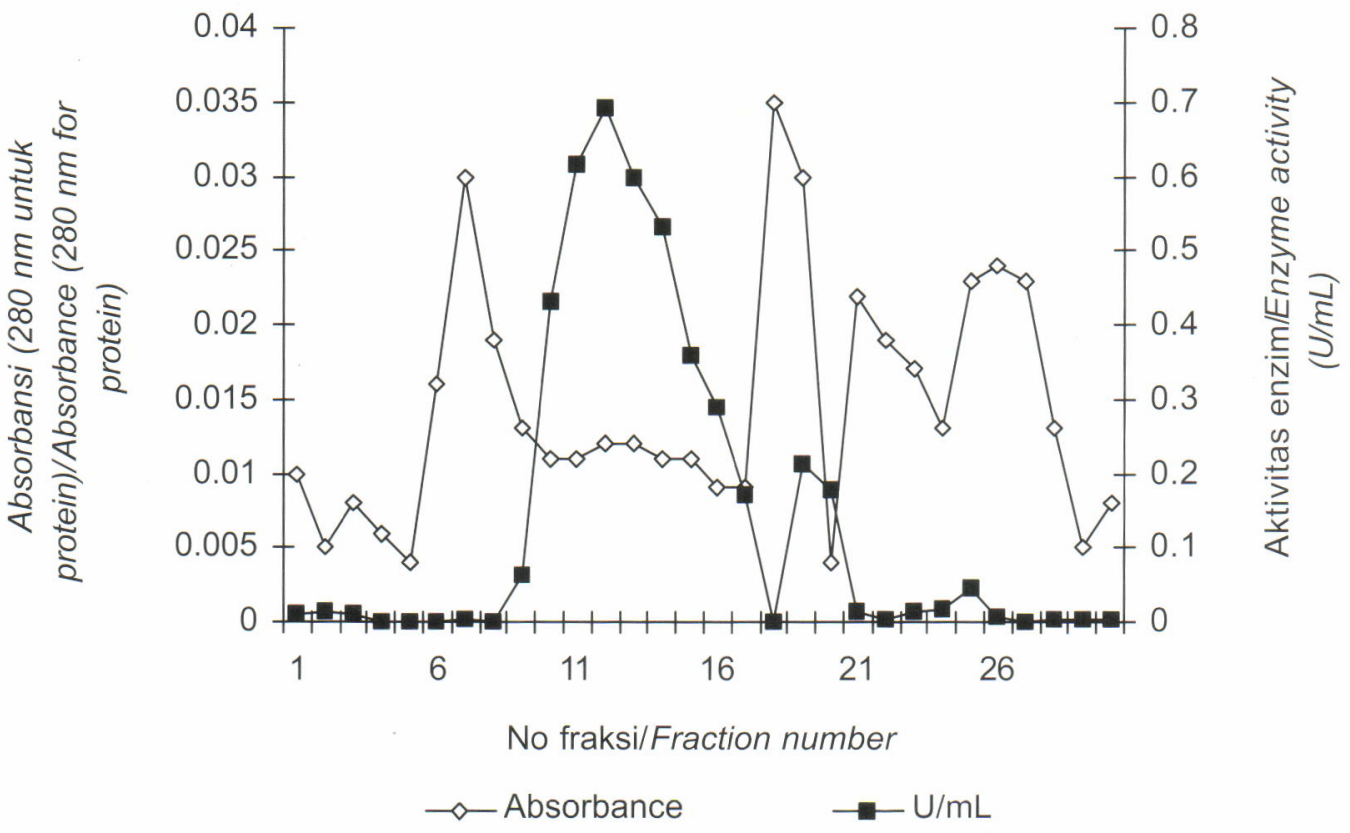

Gambar 6. Profil elusi pada pemurnian fraksi F1 dengan gel filtrasi menggunakansephadex G-75.

Figure 6. Elution profile of F1 purified with filtration gel using sephadex G-75. 
merupakan salah satu kunci untuk mendapatkan pemisahan yang baik (Roe, 1989; Eriksson, 1998). Dalam percobaan ini terlihat bahwa kecepatan elusi yang rendah $(2 \mathrm{~mL} / \mathrm{jam})$ berperan dalam mendapatkan fraksi murni F2. Kecepatan elusi diatur dengan mempertimbangkan sifat protein enzim yang akan dipisahkan yang akan berhubungan dengan suhu ruangan tempat pemurnian dilakukan. Protein yang bersifat tidak tahan panas tentunya memerlukan suhu ruang pemurnian yang lebih rendah dan kecepatan elusi yang tidak terlalu rendah dibanding protein yang bersifat tahan panas. Karena itu, salah satu keuntungan menggunakan enzim tahan panas atau termostabil adalah penanganannya, termasuk dalam tahap pemurnian, yang lebih mudah.

Perolehan enzim hasil pemisahan dan tingkat kemurnian yang diperoleh dapat dilihat pada Tabel 2 . Enzim kitosanase murni (F2) diperoleh melalui satu kali tahapan pemurnian dengan perolehan hasil $29 \%$ hidrofobik, dengan protokol sebagai berikut: adsorpsi protein enzim pada matriks dengan menggunakan amonium sulfat ( $30 \% \mathrm{TK}$ ), dan elusi dengan gradien amonium sulfat ( $10 \%-0 \%$ TK), dengan kecepatan 2 $\mathrm{mL} / \mathrm{jam}$. Selain fraksi F2, didapat 3 fraksi lain yang belum murni. Perolehan fraksi F2 adalah 29\% dengan kelipatan kemurnian 26 kali.

\section{DAFTAR PUSTAKA}

Anonymous. 2001. Turning refuse into value: Developing news biotech products from seafood processing waste. Science Bulletin July. 33(7): 2-4.

Bollag, D.M. and Edelstein. 1991. Protein Methods. New York. Wiley-Liss. $230 \mathrm{pp}$

Chasanah, E., Suhartono, MT., Hwang, J.K., and Pyun, YR. 2002. Characterization of chitosanase enzyme from thermophile bacteria Bacillus licheniformis MB2. The fifth JSPS-DHGE International Seminar: Empowerment of Marine Healthy Foods and

Tabel 2. Hasil dan tingkat kemurnian enzim kitosanase ketika dimurnikan dengan kolom interaksi hidrofobik yang dilanjutkan dengan gel filtrasi

Table 2. Yield and purification fold of chitosanase purified with hydrophobic interaction chromatography followed by gel filtration

\begin{tabular}{|c|c|c|c|c|c|c|}
\hline Tahapan/Steps & $\begin{array}{l}\text { Volume } \\
\qquad(\mathrm{mL})\end{array}$ & $\begin{array}{l}\text { Protein } \\
(\mathrm{mg} / \mathrm{mL})\end{array}$ & $\begin{array}{l}\text { Aktivitas/ } \\
\text { Activity } \\
(U / m L)\end{array}$ & $\begin{array}{c}\text { Aktivitas } \\
\text { spesifik/ } \\
\text { Specific } \\
\text { activity }(\mathrm{U} / \mathrm{mg})\end{array}$ & $\begin{array}{l}\text { Hasil/ } \\
\text { Yield }\end{array}$ & $\begin{array}{c}\text { Kelipatan } \\
\text { kemurnian/ } \\
\text { Purification } \\
\text { fold }\end{array}$ \\
\hline $\begin{array}{l}\text { Ekstrak kasar/Crude extract } \\
\text { Butyl Sepharose 4FF: }\end{array}$ & 150 & 0.277 & 0.412 & 1.487 & $100 \%$ & $1 x$ \\
\hline F1 & 50 & 0.038 & 0.537 & 14.05 & $43 \%$ & $9.5 \times$ \\
\hline F2 & 30 & 0.016 & 0.613 & 38.31 & $29 \%$ & $25.8 \times$ \\
\hline $\begin{array}{l}\text { Ultra filtrasi F1/Ultra filtration F1 } \\
\text { Sephadex G-75: }\end{array}$ & 23 & 0.061 & 4.505 & 73.853 & $167 \%$ & $49.7 \times$ \\
\hline $\mathrm{F} 1 \mathrm{a}$ & 66 & 0.011 & 0.59 & 53.64 & $63 \%$ & $36 x$ \\
\hline $\mathrm{F} 1 \mathrm{~b}$ & 34.5 & 0.045 & 0.194 & 4.311 & $10.80 \%$ & $2.9 x$ \\
\hline
\end{tabular}

dan mampu meningkatkan kelipatan kemurnian 26 kali. Laporan mengenai penggunaan kolom interaksi hidrofobik dengan matriks Phenyl Sepharose untuk memurnikan enzim fosfatase asam dari matriks tulang cortical bovine memperoleh enzim murni $92 \%$ dengan tingkat kemurnian 13 kali (Eriksson, 1998).

\section{KESIMPULAN}

Fraksi murni F2 kitosanase dari Bacillus licheniformis MB-2 berhasil dipisahkan dengan menggunakan kolom kromatografi sistem interaksi
Nutraceuticals Strengthening the Asian Region. IPB, Bogor.

Chasanah, E. 2002. Purification of chitosanase enzyme from thermophile bacteria Bacillus licheniformis MB2 using cationic matrix. Unpublished.

Cheng, CY and Li, YK. 2000. An Aspergillus chitosanase with potential for large scale preparation of chitosan oligosaccharides. Biotechnol. Appl. Biochem. 32: 197-203.

Choi, YJ., Kim, EJ., Piao, Z., Yun, YC., and Shin, YC. 2004. Purification and characterization of chitosanase from Bacillus sp. Strain KCTC 0377BP and its application 
for the production of chitosan oligosaccharides. Appl. Environ. Microbial. 70: 4522-4531

Eriksson, KO. 1998. Hydrophobic interaction chromatography. In Jan-Christer, J. and Ryden, L. (eds). Protein Purification: principles, high resolution methods, and application. 2nd ed. Wiley-Liss, New York. 694 pp.

Kimoto, H., Kusaoke, H., Yamamoto, I., Fujii, Y., Onodera, T. and Taketo, A. 2002. Biochemical and genetic properties of Paenibacillus Glycosyl Hydrolase having chitosanase and discoidin domain. J. Biol. Chem. 277(17): 14695-14702.

Kurakake, M., Yo-U, S., Nakagawa, K., Sugihara, M. and Komaki, T. 2000. Properties of chitosanase from Bacillus cereus S1. Current Microbiol. 40: 6-9.

Park, JK., Shimono, K., Ochiai, N., Shigeru, K., Kurita, M., Ohta, Y., Tanaka, K., Matsuda, H., and Kawamukai, M. 1999. Purification, chracterization and gene analysis of a chitosanase (Cho A) from Matsuebacter chitosanotabidus 3001. J. Bacteriol. 181(21): 66426649.

Roe, S. 1989. Separation based on structure in Harris, ELV. and Angal, S. (eds.). Protein Purification Methods. IRL Press. Oxford University, $317 \mathrm{pp}$.

Seino, H., Tsukuda, K., and Shimasue, Y. 1991. Properties and action pattern of chitosanase from Bacillus sp. PI-7S. J. Agric. Biol. Chem. 55(9): 2421-2423.
Shimosaka, M., Nogawa, M.,Wang, XY., Kumehara, M., and Okazaki, M. 1995. Production of two chitosanase from a chitosanase assimilating bacterium, Acinetobacter sp strain CHB 101. Appl. Environ. Microbiol. 61(2): 438-442.

Somashekar, D. and Joseph, R. 1996. Chitosanases : properties and applications: A review. Bioresource Technol. 55: 35-45.

Trudel, J. and Asselin, A. 1989. Detection of chitinase activity after Polyacrylamide Gel electrophoresis. Anal Biochem. 178: 302-366.

Tsigos, I., Martinou, A., Kafetzopolous, D., and Bouriotis, V. 2000. Chitin deacetylases: New, versatile tools in biotechnology. TIBTECH. 18: 305-312.

Uchida, Y. and Ohtakara, A. 1998. Chitosanase from Bacillus species. Methods in enzymology. 161: 501506.

Yoshihara, K., Hosokawa, J., Kubo, T., Nishiyama, M. and Koba, Y. 1992. Purification and properties of a chitosanase from Pseudomonas sp H-14. J. Biosc. Biotech. Biochem. 56(6): 972-973.

Yoon, HG., Kim, HY., Kim, HK., Hong, BS., Shin, DH., and Cho, HY. 2001. Thermostable chitosanase from Bacillus sp strain CK4 : its purification, characterization and reaction patterns. J. Biosci. Biotechnol. Biochem. 65(4): 802-809. 
